\title{
Medicinal Plants of Chile: Evaluation of their Anti-Trypanosoma cruzi Activity
}

Orlando M. Muñoz ${ }^{\mathrm{a}, *}$, Juan D. Maya ${ }^{\mathrm{b}}$, Jorge Ferreira ${ }^{\mathrm{b}}$, Philippe Christen ${ }^{\mathrm{c}}$, José San Martin ${ }^{\mathrm{d}}$, Rodrigo López-Muñoz ${ }^{\mathrm{b}}$, Antonio Morello ${ }^{\mathrm{b}}$, and Ulrike Kemmerling ${ }^{\mathrm{b}}$

a Department of Chemistry, Faculty of Science, University of Chile, Santiago, Chile. Fax: 56-2 2713888. E-mail: omunoz@uchile.cl

b Institute of Biological Sciences, Faculty of Medicine, University of Chile, Santiago, Chile

c School of Pharmaceutical Sciences, EPGL, University of Geneva,

University of Lausanne, 30, Quai Ernest-Ansermet, CH-1211 Geneva 4, Switzerland

d Instituto de Biología Vegetal y Biotecnología, Universidad de Talca, Talca, Chile

* Author for correspondence and reprint requests

Z. Naturforsch. 68c, 198-202 (2013); received December 15, 2011/March 7, 2013

The extracts of several plants of Central Chile exhibited anti-Trypanosoma cruzi trypomastigotes activity. Most active extracts were those obtained from Podanthus ovatifolius, Berberis microphylla, Kageneckia oblonga, and Drimys winteri. The active extract of Drimys winteri $\left(\mathrm{IC}_{50} 51.2 \mu \mathrm{g} / \mathrm{mL}\right)$ was purified and three drimane sesquiterpenes were obtained: polygodial, drimenol, and isodrimenin. Isodrimenin and drimenol were found to be active against the trypomastigote form of $T$. cruzi with $\mathrm{IC}_{50}$ values of 27.9 and $25.1 \mu \mathrm{M}$, respectively.

Key words: Anti-Trypanosoma cruzi, Drimenol, Isodrimenin

\section{Introduction}

Chagas' disease, caused by Trypanosoma cruzi, is among the most important endemic parasitic diseases. Approximately 16 to 18 million people are infected in large areas of Latin America (Fournet and Munoz, 2002). Over 1 million of them will die of the disease unless considerable advances are made (Maguire, 2006). Furthermore, there is increasing evidence that it may be an emerging problem in the developed world, with more than 100,000 infected persons living in the United States of America alone (Maguire, 2006).

The drugs used for the treatment of this disease are nifurtimox, a nitrofuran derivative, and benznidazole, a nitroimidazole derivative. Both drugs generate severe side effects, and nifurtimox is no longer used in several countries because of its toxicity (Castro et al., 2006; Croft et al., 2005). Consequently, the need for effective anti-Trypanosoma compounds with less toxicity stimulates the search for natural products as novel drug candidates with a potential clinical use (Hoffmann et al., 1992; González et al., 1990).

The aim of the present work was to assess the in vitro activity of some Chilean plant extracts against the trypomastigote forms of Trypanosoma cruzi. Thirty-one species of plants belonging to 28 genera in 21 families were investigated. The most active extracts were those obtained from Podanthus ovatifolius, Berberis microphylla, Kageneckia oblonga, and Drimys winteri.

Drimys winteri (Winteraceae) is a tree of economic and social importance with medicinal properties in Chile. This plant contains several sesquiterpenes of the drimane type. Leaves of Drimys winteri are used in Chilean folk medicine as analgesic and in anti-inflammatory medications (Houghton and Manby, 1998; San Martin, 1983; Cotoras et al., 2001; Muñoz and Fajardo, 2005; Muñoz et al., 2001; Ruiz et al., 2010).

\section{Experimental}

\section{General}

Column chromatography (CC) was carried out using silica gel 60G (Merck Darmstadt, Germany). Thin-layer chromatography (TLC) was performed on silica gel GF254 (Merck) with (i) $n$-hexane/ethyl acetate $(8: 2, \mathrm{v} / \mathrm{v})$ and (ii) $n$-hexane/acetone (8:2) as eluents. Spots were detected under UV light or by spraying with LiebermannBurchard reagent and heating to $110{ }^{\circ} \mathrm{C}$ for $2 \mathrm{~min}$. 
Preparative TLC was performed on $2 \mathrm{~mm}$ thick silica gel F254 plates (Merck) and on a chromatotron (Harrison-Research Model 7924 T; Palo Alto, CA, USA) with 1-mm and 2-mm discs, using silica gel 60 PF 254 (Merck). Flash chromatography was performed on silica gel $60 \mathrm{H}$ (Merck) with an $n$-hexane/ethyl acetate gradient $(0,1,5$, $10,50,100 \%$ ethyl acetate). Melting points are uncorrected. Optical rotations were measured with a Perkin Elmer 241 MC polarimeter (Waltham, MA, USA).

${ }^{1} \mathrm{H}$ and ${ }^{13} \mathrm{C}$ NMR spectra were recorded in $\mathrm{CDCl}_{3}$, at 400 and $500 \mathrm{MHz}$ for ${ }^{1} \mathrm{H} \mathrm{NMR}$ and 100 and $125 \mathrm{MHz}$ for ${ }^{13} \mathrm{C} \mathrm{NMR}$, on a Bruker Avance AM-400 spectrometer (Karlsruhe, Germany).

The ${ }^{1} \mathrm{H}$ NMR spectra used for the measurement of the coupling constants and the HMBC spectra used for the determination of the connectivity of substituents were recorded in $\mathrm{CDCl}_{3}$ on a Bruker-DRX $500 \mathrm{MHz}$ instrument. The ${ }^{1} \mathrm{H}$ Larmor frequency was determined using a $5-\mathrm{mm}$ QPN direct detection probe. Chemical shifts ( $\delta$ in $\mathrm{ppm})$ are relative to the internal standard tetramethylsilane (TMS). 1D $\left({ }^{1} \mathrm{H},{ }^{13} \mathrm{C}\right)$ and $2 \mathrm{D}(\mathrm{COSY}$, HMQC, HMBC) experiments were performed using standard Bruker microprograms.

\section{Plant materials}

Ethnopharmacological and ethnobotanical literature was obtained from Instituto de Biología Vegetal y Biotecnología, Universidad de Talca, Talca, Chile, and from the Departamento de Botanica, Facultad de Ciencias, Universidad de Chile, Santiago, Chile. Thirty-one plant species were included in the study and collected in Central Chile (Coastal Range, Maule Region) during the flowering season in January 2009 and 2010, and identified by one of us (J. S. M.). Voucher specimens are deposited and kept in the Instituto de Biología Vegetal y Biotecnología, Universidad de Talca. Plants used in this study are listed in Table I.

\section{Extraction}

The collected plants were washed with distilled water and dried on absorbing paper at an ambient temperature of $25-30{ }^{\circ} \mathrm{C}$ in open air in the shade for 5-10 d. The dried plant samples were powdered and stored at ambient temperature in amber glass bottles until use. The powdered plant materials $(10.0-80.0 \mathrm{~g})$ were extracted with dichloromethane $(4.0 \mathrm{~mL} / \mathrm{g}$ plant $)$ or methanol/ water $(4: 1, \mathrm{v} / \mathrm{v} ; 4.0 \mathrm{~mL} / \mathrm{g}$ plant $)$ for $4 \mathrm{~h}$ at room temperature. The extracts were filtered and evaporated to dryness under vacuum. The residues

Table I. Chilean plant species used in this study.

\begin{tabular}{|c|c|}
\hline No. Species, family & No. Species, family \\
\hline 1 Podanthus ovatifolius Lag., Asteraceae & 18 Margyricarpus pinnatus (Lam.) Kuntze, Rosaceae \\
\hline 2 Cryptocarya alba (Mol.) Looser, Lauraceae & 19 Pseudognaphalium vira vira (Mol.) A. Anderb., \\
\hline 3 Escallonia illinita K. Presl., Saxifragaceae & \\
\hline $\begin{array}{l}4 \text { Blepharocalyx cruckshanksii (H. et A.) Nied., } \\
\text { Myrtaceae }\end{array}$ & $\begin{array}{l}20 \text { Eupatorium salvia Colla, Asteraceae } \\
21 \text { Baccharis concava (Ruiz et Pav.) Pers., Asteraceae }\end{array}$ \\
\hline 5 Satureja gilliesii (Graham) Briq., Lamiaceae & 22 Viviania crenata (Hook.) G. Don ex H. et A., Ru- \\
\hline 6 Drimys winteri J. R. Forst. et G. Forst., Winteraceae & biaceae \\
\hline 7 Luma chequen (Mol.) A. Gray, Myrtaceae & 23 Fabiana imbricata Ruiz et Pav., Solanaceae \\
\hline 8 Luma apiculata (DC.) Burret, Myrtaceae & 24 Myoschilos oblonga Ruiz et Pav., Santalaceae \\
\hline 9 Fuchsia magellanica Lam., Onagraceae & 25 Berberis darwinii Hook., Berberidaceae \\
\hline 10 Colliguaja odorifera Mol., Euphorbiaceae & 26 Maytenus chubutensis (Speg.) Lourt., O'Donell et \\
\hline 11 Ugni molinae Turcz., Myrtaceae & elastraceae \\
\hline $\begin{array}{l}12 \text { Alstroemeria revoluta Ruiz et Pav., Amaryllidaceae } \\
13 \text { Pitavia punctata Mol., Rutaceae }\end{array}$ & $\begin{array}{l}27 \text { Myrceugenia chrysocarpa (O. Berg) Kausel, Myrta- } \\
\text { ceae }\end{array}$ \\
\hline 14 Podocarpus saligna D. Don, Podocarpaceae & 28 Elytropus chilensis (A. DC.) Muell. Arg., Apocyn- \\
\hline 15 Lapageria rosea Ruiz et Pav., Philesiaceae & \\
\hline 16 Schinus latifolius (Gill. ex Lindl.) Engler, Anacar- & 29 Berberis serrato-dentata Lechler, Berberidaceae \\
\hline 17 Kageneckia oblonga Ruiz et Pav., Rosaceae & $\begin{array}{l}30 \text { Berberis microphylla } \text { G. Forst., Berberidaceae } \\
31 \text { Pseudopanax laetevirens (Gay) Franch., Araliaceae }\end{array}$ \\
\hline
\end{tabular}


were weighed and solubilized in dimethylsulfoxide (DMSO) for biological assays.

\section{Culture of trypomastigotes}

African green monkey Vero cells were infected by co-incubation of a culture of epimastigotes in the late stationary phase, which contains about $5 \%$ of the infective trypomastigote form (Contreras et al., 1985). Subsequently, the trypomastigotes harvested from this culture were used to further reinfect cultures of Vero cells at a density of $1 \cdot 10^{6}$ cells $/ 25 \mathrm{~cm}^{2}$, in a proportion of parasites to cells of $2: 1$. Vero cell cultures infected with trypomastigotes were incubated at $37^{\circ} \mathrm{C}$ in humidified air and $5 \% \mathrm{CO}_{2}$ for 5-7 d. After that time, the culture medium was collected and centrifuged at 3,000 x $g$ for $5 \mathrm{~min}$, and the resulting trypomastigote-containing pellet was resuspended at a density of $1 \cdot 10^{7}$ parasites/mL in RPMI 1640 culture medium (without phenol red).

\section{Trypomastigote viability assay}

Viability assays were performed using the formazan formation method, called 3-(4,5-dimethylthiazol-2-yl)-2,5-diphenyltetrazolium bromide (MTT) assay, as previously described (Faundez et al., 2005; Mosmann, 1986). Briefly, $1 \cdot 10^{7}$ trypomastigotes were incubated in RPMI 1640 culture medium at $37^{\circ} \mathrm{C}$ for $24 \mathrm{~h}$ with and without addition of the extracts at final concentrations of $10-500 \mu \mathrm{g} / \mathrm{mL}$. Formazan formation was measured at $570 \mathrm{~nm}$ in a multi-well reader (Lab systems Multiskan MS, Vantaa, Finland).

\section{Characterization of compounds isolated from Drimys winteri}

Barks of D. winteri were dried in an air-forced oven at $40{ }^{\circ} \mathrm{C}$ for $48 \mathrm{~h}$. Four hundred fifty $\mathrm{g}$ of chopped and powdered bark material were extracted with $n$-hexane $(2 \times 2.0 \mathrm{~L})$ for $24 \mathrm{~h}$ in a Soxhlet extractor. Filtration followed by evaporation of the solvent under reduced pressure $(0.21$ atm) at $25-30{ }^{\circ} \mathrm{C}$ gave a yellowish oily residue $(30.0 \mathrm{~g})$.

The crude $n$-hexane extract was first subjected to flash CC (silica gel, 230-400 mesh, $650 \mathrm{~g}$ ), then fractionated by gradient elution $(100 \% n$-hexane to $100 \%$ ethyl acetate) to give individual fractions which were further purified by two silica gel columns. Elution with $n$-hexane/ethyl acetate
(98:2-90:10) yielded $2.84 \mathrm{~g}$ of a yellow mixture consisting of two compounds. Further separation on the chromatotron afforded $0.85 \mathrm{~g}$ of polygodial and $0.015 \mathrm{~g}$ of drimenol. The ethanol fraction $(2.5 \mathrm{~g})$ was subjected to CC on silica gel and separated by gradient elution (dichloromethane/methanol) to afford isodrimenin. The compounds were identified by spectral data (IR, ${ }^{1} \mathrm{H}$ NMR, and ${ }^{13} \mathrm{C}$ NMR), which were in good agreement to those previously published (Cicció, 1984; Jansen and Groot, 2004; McCallion, 1982; Aasen et al., 1977; White and Burton, 1985), and by direct comparison with authentic samples.

\section{Results and Discussion}

Table I shows the 31 plants used in this study from which dichloromethane and methanol/water extracts were prepared and tested against trypomastigotes in concentrations of up to $500 \mu \mathrm{g} / \mathrm{mL}$. Table II shows the activities of extracts of Podanthus ovatifolius, Berberis microphylla, Kageneckia oblonga, and Drimys winteri, the four plants that produced significant inhibition in the MTT test. These plant extracts exhibited activities between 7 and $5 \%$ of those of the standard compounds benznidazole or nifurtimox, respectively. The extracts from all other plants in Table I showed an $\mathrm{IC}_{50}$ value higher than $500 \mu \mathrm{g} / \mathrm{mL}$. Table III shows the activities of isodrimenin, drimenol, and polygodial, the three

Table II. Activity of Chilean plant extracts on the Trypanosoma cruzi trypomastigotes.

\begin{tabular}{lcc}
\hline Plant & Extract & \begin{tabular}{c} 
MTT viability test $_{\mathrm{IC}_{50}[\mu \mathrm{g} / \mathrm{mL}]}$ \\
\hline $\begin{array}{l}\text { Mitique (Podanthus } \\
\text { ovatifolius) }\end{array}$
\end{tabular} \\
$\begin{array}{l}\text { Michay (Berberis } \\
\text { microphylla) }\end{array}$ & Methanol/water & $40.1 \pm 3.0$ \\
$\begin{array}{l}\text { Bollén (Kageneckia } \\
\text { oblonga) }\end{array}$ & $38.4 \pm 5.0$ \\
$\begin{array}{l}\text { Canelo (Drimys } \\
\text { winteri) }\end{array}$ & Dichloro- & $51.2 \pm 2.0$ \\
$\begin{array}{l}\text { Nifurtimox } \\
\text { Benznidazole }\end{array}$ & methane & $4.6 \pm 0.1$ \\
\hline
\end{tabular}

The MTT assay was carried out with the trypomastigote form of $T$. cruzi. Extracts were used at final concentrations of $10,15,20,50,100$, and $500 \mu \mathrm{g} / \mathrm{mL}$. $\mathrm{IC}_{50}$ values were calculated from drug concentration-response curves (see Experimental). Results are shown as the average \pm standard deviation of three independent experiments. 
Table III. Activity of compounds isolated from Drimys winteri upon the Trypanosoma cruzi trypomastigote form.

\begin{tabular}{lr}
\hline Compound & \multicolumn{1}{c}{$\mathrm{IC}_{50}[\mu \mathrm{M}]$} \\
\hline Isodrimenin & $27.9 \pm 0.3$ \\
Drimenol & $25.1 \pm 0.5$ \\
Polygodial & $120.4 \pm 1.5$ \\
Nifurtimox & $16.1 \pm 0.2$ \\
Benznidazole & $32.2 \pm 0.3$ \\
\hline
\end{tabular}

The activity was measured on $T$. cruzi trypomastigotes using the MTT method at the concentrations of 10, 15, $20,50,100$, and $200 \mu \mathrm{M} . \mathrm{IC}_{50}$ values were calculated from drug concentration-response curves (see Experimental). Results are shown as the average \pm standard deviation of three independent experiments.

sesquiterpenes isolated from the stem bark of Drimys winteri (Fig. 1). The results show that polygodial, the most active antifungal (Kubo et al., 2001), antifeedant (Zapata et al., 2009), and antibacterial (Kubo et al., 2005) from D. winteri, has a weak anti-Trypanosoma activity with respect to the other sesquiterpenes. Isodrimenin and drimenol showed similar activities as nifurtimox or benznidazole (Table III). Some compounds of the other three active plant extracts are being isolated and their antiparasite activity will be tested later.

Aasen A. J., Nishida J., Enzell C. D., and Appel H. H. (1977), The structure of $(11 \xi, 12 \xi)-11,12$-di(7-drimen11-oxy)-11,12-epoxy-7-drimene. Acta Chem. Scand. 31B, $51-55$.

Castro J. A., Mecca M. M., and Bartel L. C. (2006), Toxic side effects of drugs used to treat Chagas' disease (American trypanosomiasis). Hum. Exp. Toxicol. 25, $471-479$.

Cicció J. (1984), Poligodial, constituyente mayoritario de la corteza de Drimys granadensis L. F. (Winteraceae). Ing. Cienc. Quím. 8, 45-46.

Contreras V. T., Salles J. M., Thomas N., Morel C. M., and Goldenberg S. (1985), In vitro differentiation of Trypanosoma cruzi under chemically defined conditions. Mol. Biochem. Parasitol. 16, 315-327.

Cotoras M., Garcia C., Lagos C., Folch C., and Mendoza L. (2001), Antifungal activity on Botrytis cinerea of flavonoids and diterpenoids isolated from the surface of Pseudognaphalium spp. Bol. Soc. Chil. Quím. 46, $433-440$.
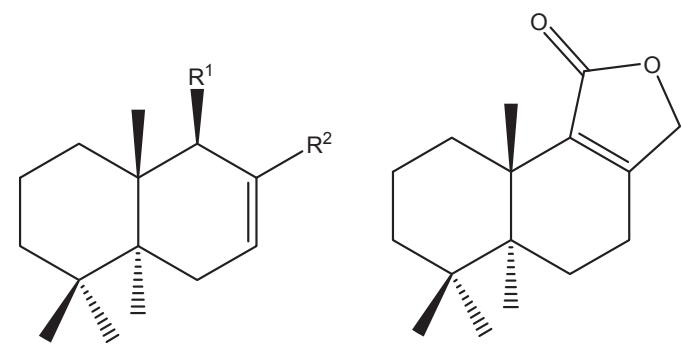

Polygodial $\quad \mathrm{R}^{1}=\mathrm{R}^{2}=\mathrm{CHO}$

Drimenol $\quad \mathrm{R}^{1}=\mathrm{CH}_{2} \mathrm{OH} ; \mathrm{R}^{2}=\mathrm{CH}_{3}$

Isodrimenin

Fig. 1. Chemical structure of compounds isolated from Drimys winteri.

Plant metabolites active against $T$. cruzi have been recently reviewed by our laboratories (Maya et al., 2007; Salas et al., 2011), and we concluded that the compounds isodrimenin and drimenol isolated from Drimys winteri represent new basic lead structures to obtain new selective antichagasic drugs.

\section{Acknowledgements}

This research was funded by World Bank-CONICYT ACT-112 and Fondecyt-Chile No. 1090078 and 11110182. The authors thank Dr. Yedy Israel for his comments on the manuscript.

Croft S. L., Barrett M. P., and Urbina J. (2005), Chemotherapy of trypanosomiases and leishmaniasis. Trends Parasitol. 21, 508-512.

Faundez M., Pino P., Letelier P., Ortiz C., López R., Seguel C., Ferreira J., Pavani M., Morello A., and Maya J. D. (2005), Buthionine sulfoximine increases the toxicity of nifurtimox and benznidazole to Trypanosoma cruzi. Antimicrob. Agents Chemother. 49, 126-130.

Fournet A. and Munoz V. (2002), Natural products as trypanocidal, antileishmanial and antimalarial drugs. Curr. Top. Med. Chem. 2, 1215-1237.

González A. G., Bermejo J., Diaz J., Rodriguez E. M., Perez A., Yanes A., Rauter P., and Pozo J. (1990), Diterpenes and other constituents of Eupatorium salvia. Phytochemistry 29, 321-323.

Hoffmann A., Lastra J., Veghazi E., and Farga C. (1992), Plantas medicinales de uso común en Chile, 2 ed. Fundación Cludio Gay, Santiago, Chile, p. 273. 
Houghton P. and Manby J. (1998), Medicinal plants of the Mapuche. J. Ethnopharmacol. 13, 89-103.

Jansen B. M. and Groot A. (2004), Occurrence, biological activity and synthesis of drimane sesquiterpenoids. Nat. Prod. Rep. 21, 449-477.

Kubo I., Fujita K., and Lee S. H. (2001), Antifungal mechanism of polygodial. J. Agric. Food Chem. 49, 1607-1611.

Kubo I., Fujita K., Lee B., and Ha T. J. (2005), Antibacterial activity of polygodial. Phytother. Res. 19, 1013-1017.

Maguire J. H. (2006), Chagas' disease - Can we stop the deaths? N. Engl. J. Med. 355, 760-761.

Maya J. D., Cassels B. K., Vasquez P., Ferreira J., Faúndez M., Galanti N., Ferreira A., and Morello A. (2007), Mode of action of natural and synthetic drugs against Trypanosoma cruzi and their interaction with the mammalian host. Comp. Biochem. Physiol. Part A: Mol. Integr. Physiol. 146, 601-620.

McCallion R. F. (1982), Antibiotic substances from New Zealand plants. II. Polygodial, an anti-Candida agent from Pseudowintera colorata. Planta Med. 44, $134-138$.

Mosmann T. (1983), Rapid colorimetric assay for cellular growth and survival: application to proliferation and cytotoxicity assays. J. Immunol. Methods 65 , $55-63$.

Muñoz O. and Fajardo V. (eds.) (2005), Flora de Chile: Biología, farmacología y química. Universidad de Playa Ancha, Valparaíso, Chile, p. 227.
Muñoz O., Montes M., and Wilkomirsky T. (2001), Plantas medicinales de uso en Chile: Química y Farmacología, 2 ed. Editorial Universitaria, Santiago, Chile.

Ruiz A., Gutierrez I., Mardones C., Vergara C., Herlitz E., Vega M., Dorau C., Winterhalter P., and Von Baer D. (2010), Polyphenols and antioxidant activity of calafate (Berberis microphylla) fruits and other native berries from Southern Chile. J. Agric. Food Chem. 58, 6081-6089.

Salas C., Faundez M., Morello A., Maya J. D., and Tapia R. (2011), Natural and synthetic naphthoquinones active against Trypanosoma cruzi: an inicial step towards new drugs for Chagas disease. Curr. Med. Chem. 18, 144-161.

San Martin J. (1983), Medicinal plants in Central Chile. Econ. Bot. 37, 216-227.

White J. D. and Burton P. J. (1985), Synthese of the insect antifeedant $( \pm)$-cinnamodial and the drimane sesquiterpenoids $( \pm)$-isodrimenin and $( \pm)$-fragrolide. J. Org. Chem. 50, 357-364.

Zapata N., Budia F., Viñuela E., and Medina P. (2009), Antifeedant and growth inhibitory effects of extracts and drimanes of Drimys winteri stem bark against Spodoptera littoralis (Lep., Noctuidae). Ind. Crops Prod. 30, 119-125. 